\title{
Tukea vai ilkeilyä verkkokeskustelupalstalla?
}

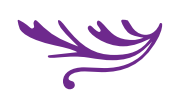

\author{
Rajanveto tuen ja ilkeilyn välillä on selvää, mutta millaista on \\ piiloilkeily verkon keskustelupalstoilla? Kommenteille on ainakin \\ ominaista, että ilkeily on epäsuoraa ja tulkinnanvaraista, eikä sitä \\ osoiteta suoraan keskustelun aloittajalle.
}

ARTIKKELINI LIITTYY tietokonevälitteisen viestinnän (computer-mediated communication, CMC) tutkimuskenttään. Siihen kuuluu laajasti ottaen tietokoneiden avulla tapahtuva vuorovaikutus, mutta erityisesti tekstipohjainen viestintä (ks. Matikainen 2006, 177). Käsittelen ainoastaan anonyymeja verkkokeskustelupalstoja tietokonevälitteisen viestinnän muotona (vrt. Ristolainen, Hankonen ja Lehtinen 2007, 276). Matikaisen (2006, 180) mukaan vähentyneiden sosiaalisten vihjeiden mallin (Spears \& Lea 1992, 30-34) ajatuksena on, että "sosiaalisten ja kontekstuaalisten vihjeiden puute johtaa heikompiin sosiaalisiin normeihin ja rajoitteisiin”. Toisaalta anonyymius ja tuntemattomien kanssa keskustelu auttavat vaikeiden asioiden avoimempaa esilletuomista ja käsittelyä verrattuna kasvokkain tapahtuvaan vuorovaikutukseen (Drentea \& Moren-Cross 2005, 921). Verkkokeskustelussa viestinnän emotionaaliseksi tehostamiseksi voidaan käyttää sanojen lisäksi muita keinoja, kuten isoja kirjaimia, hymiöitä ja välimerkkejä (Ahti 2011, 14).

Keskustelupalstoja voi pitää yhtenä informaalisen oppimisen areenana: siellä haetaan ja saadaan neuvoja ja tukea ongelmallisiin tilanteisiin. Verkon keskustelupalstat voivat tarjota turvallisen ja nimettömän tukikanavan erilaisten ongelmatilanteiden pohdintaan. Verkkokeskustelun sanotaankin tarjoavan arvostelusta vapaan keskustelufoorumin (O'Connor \& Madge 2004, 351; Drentea \& Moren-Cross 2005, 921). Palstoilta voidaan hakea tukea ja neuvoja esi- 
merkiksi perheeseen liittyviin ongelmiin (Plantin \& Daneback 2009). Tässä artikkelissa keskityn yleiseen nimettömään keskustelupalstaan, joten huomioni on keskustelun informaalisissa neuvoissa ja tiedoissa. En siis puhu asiantuntijoiden jakamasta formaalisista tiedoista tai neuvoista. Tarkastelen, millaisena tukikanavana yleinen keskustelufoorumi toimii isovanhempien ja lastenlasten suhteita käsittelevillä palstoilla.

Verkosta saatava tuki voidaan jakaa emotionaaliseen, välineelliseen sekä yhteisyyden rakentamiseen (Drentea \& Moren-Cross 2005, 929 -937; Brady \& Guerin 2010, 14, 15). Emotionaalista tukea haetaan turhauttaviin tilanteisiin. Verkkokeskustelusta toivotaan ymmärtämystä esitettyyn tilanteeseen ja siitä tehtyihin tulkintoihin (Drentea \& Moren-Cross 2005,930 .) Stressaavia tilanteita ja turhautumista puretaan verkossa ja toisilta keskustelijoilta odotetaan tuen saamista (Brady \& Guerin 2010, 14, 15). Tällöin emotionaalinen tuki voi saada tukea hakeneen osapuolen tuntemaan olonsa paremmaksi (Colineau \& Paris 2010, 143).

Välineellisellä tuella tarkoitetaan tietojen ja asiantuntijaneuvojen jakamista (Brady \& Guerin 2010, 14, 15). Välineellistä tukea voi myös luonnehtia ongelmakeskeiseksi tueksi, jossa tarjotaan erilaisia neuvoja ja ratkaisuja tilanteen korjaamiseksi (Fukkink 2011,247). Verkossa olevan informaation ja neuvojen laadusta ei kuitenkaan ole mitään takeita. Ongelmana on myös, että viestejä voidaan tulkita väärin, koska viestintään ei sisälly ilmeitä eikä äänenpainoja (McCormack \& Coulson 2009, 2).

Yhteisön suojelemista tapahtuu, kun keskusteluyhteisön jäsenet reagoivat yhteisön sääntöjen rikkomiseen. Ristiriitoja todennäköisesti syntyy, mikäli jotkut yksittäiset henkilöt käyttävät verkkoa ristiriitojen aikaansaamiseen tai keskustelevat aiheeseen liittymättömistä asioista. Lisäksi ristiriitoja saattaa aiheutua, jos jokin viesti koetaan arvostelevaksi tai hyökkääväksi. (Brady \& Guerin 2010, 14, 15). Sovellan edellä esiteltyä yhteisön suojelemisen logiikkaa valitsemaani yksilön suojelemisen käsitteeseen. Tarkastelen yksilön suojelun näkökulmasta seuraavia tilanteita keskustelupalstalla: ristiriitojen luomiseen puuttumista, aloittajaan kohdistuviin ilkeilyihin reagoimista, ilkeilijän moittimista sekä moittimista kes- kusteluun liittymättömiin aihepiireihin eksymisestä.

Verkkovuorovaikutus voi tarjota tukea ongelmatilanteisiin, mutta verkkokeskustelu voi olla vain oman näkökulman esiintuomista ilman pyrkimystä dialogiin keskustelukumppanin kanssa. Lisäksi verkkokeskustelussa voidaan tarkoituksellisesti tuottaa vastakkainasetteluja, osoittaa omaa erinomaisuutta ja haukkua vastapuolta. (Matikainen 2006, 96.) Sosiolingvistiikan professori Claudine Moïse puhuu elinympäristön verbaalisen konfliktoitumisen yleistymisestä ja sähköisten viestimien käyttämisestä ilkeilyyn (Yliopisto-lehti 2012, 8 mukaan). Vanhemmuuteen liittyvät tilanteet ja käyttäytymisratkaisut herättävät varsin usein kiistoja, joten vastakkaiset mielipiteet voivat saada aikaan voimakkaitakin aggressioita (Dreante \& Moren-Cross 2005, 933).

Fleimaus (flaming) on käsite, jolla viitataan emotionaalisen vihamielisyyden osoittamiseen tietokonevälitteisessä kommunikoinnissa (Matikainen 2000, 56). Voidaan myös puhua kyber-aggressiosta (cyber-aggression, Grigg 2010, 143). Tällöin puhutaan usein pitkäaikaisesta tuttujen henkilöiden taholta koetusta toistuvasta kiusaamisesta. Ilkeily puolestaan on pääosin satunnaista ja lyhytaikaista, mikä erottaa sen kiusaamisesta. (Muikku-Werner 2005). Käytän ilkeilyn käsitettä fleimauksen sijasta, koska fleimaukselle ei ole hyvää suomenkielistä vastinetta. Yleisillä keskustelupalstoilla, joissa kommunikointi on satunnaista ja lyhytaikaista, onkin pääosin kyse ilkeilystä. Muikku-Wernerin $(2004,158)$ näkökulmasta poiketen en pidä ilkeilyä jatkumona, jossa toisessa päässä on leikkisä kiusoittelu1 ${ }^{1}$. Ilkeily-jatkumon toisen ääripään hän määrittää pahantahtoiseksi häijyydeksi. En itse näe näitä ilmiöitä saman ulottuvuuden ääripäinä. Ilkeilyn näen jatkumona, jonka toisessa päässä on erittäin vähäinen ilkeily ja toisessa erittäin suuri ilkeily². Ilkeilyn alalajeina pidän avointa ilkeyttä ja piiloilkeyttä. Avoin ilkeily keskustelupalstalla on vastapuolta tarkoituksellisesti loukkaava, pahansuopainen ja harkittu suoraan kohdistettu reagointi joko aloittajan esittämään ongelmatilanteeseen tai aloittajaan. Piilo-ilkeily on ilkeyttä, joka verhotaan näennäiseen kohteliaisuuteen ja jonka keinoja ovat mm. liioittelu, vähättely ja epäsuoruus. ( ks. Muikku-Werner 2004, 158.) 
Lasten ja isovanhempien suhteita käsittelevässä kirjallisuudessa voi eritellä muun muassa seuraavankaltaisia ongelmia: omien lasten eroamisesta seuraavat ongelmat lastenlasten ja isovanhempien välisissä suhteissa (esim. Barth 2004; Doyle, O’Dywer, Timonen 2010 ); anopin ja miniän väliset suhteet (esim. Turner, Young ja Black 2006) tai aikuisten lasten ja heidän vanhempiensa väliset huonot suhteet ja näiden vaikutukset lastenlasten ja isovanhempien suhteisiin. Isovanhempien oikeus olla hoitamatta lapsenlapsia herättää myös ristiriitoja (Connolly \& Ward 2008, 354,355).

\section{AINEISTO}

Artikkelissa tarkastellaan, millaista tukea ja ilkeilyä perheen ihmissuhteisiin liittyvillä lastenlasten ja isovanhempien välisiä suhteita käsittelevillä keskustelupalstoilla esiintyy. Tarkastelun aineistona ovat Suomi 24 -keskustelupalstan Isovanhempien jutut -palstan neljä keskustelun aloitusta ja niihin annetut kommentit 15.8.2012 tilanteen mukaan. Koska keskustelupalstat ovat avoimia ja keskustelun seuraaminen ei edellytä kirjautumista, pidän näitä julkisina teksteinä, jotka eivät edellytä kirjoittajien suostumuksen hankkimista (ks. Mo \& Coulson 2008, 372).

Eettisiä kysymyksiä pohdittaessa on tärkeää arvioida, kuinka haavoittavaa tai arkaluontoista aineisto on keskustelijoille. Tulkitsen, että tässä käytetyt aineistot eivät ole ongelmallisia, koska ei ole kyse esimerkiksi anorektikoista tai addiktioista kärsivistä tai muista haavoittavassa elämäntilanteessa olevista. (Turtiainen \& Östman 2013, 52, 53.) Keskustelujen aloitukset ovat aikajärjestyksessä: Kun mummot omivat lapsen (A1); En saa olla yhteydessä lapsenlapsiini (A2); Lastenlasten eriarvoisuus (A3) ja Isoäiti ei auta (A4). Tuloksissa viittaan aloituksiin (A1-A4) sillä perusteella, minkä kanssa kommentti keskustelee. Kaiken kaikkiaan keskustelupalstoilla kirjoitettiin (aloitusten lisäksi) yhteensä 255 kommenttia. Pisin kommentti oli 43 riviä ja lyhin muutaman sanan mittainen. Tutkimustuloksissa aloituspuheenvuoron esittäjää nimitetään aloittajaksi ja aloitusteemaa aloitukseksi.

Puheenvuorojen määrä aloituskeskusteluissa jakaantui seuraavasti:
- Kun mummot omivat lapsen (A1): aloittajan kommentteja 5, kommentteja yhteensä 92.

- En saa olla yhteydessä lapsenlapsiini (A2): aloittajan kommentteja 6, kommentteja yhteensä 27.

- Lastenlasten eriarvoisuus (A3): aloittajan kommentteja 9, kommentteja yhteensä 88 .

- Isoäiti ei auta (A4): aloittajan kommentteja 6, kommentteja yhteensä 48 .

Keskustelun aloitukset valitsin kuvaamaan mahdollisimman erilaisia isovanhempien ja lastenlasten sekä heidän vanhempiensa välisiin suhteisiin liittyviä ongelmia. Puheenvuorojen jakaantumisesta voi huomata, kuinka aloituksen sisältö vaikuttaa keskustelun viriämiseen. Vähiten keskustelua herättänyt aloitus viritti vain 21 (27-6) muiden kommenttia, kun taas eniten keskustelua aikaansaanut aloitus sai muilta 87 (92-5) kommenttia.

Keskustelun aloitukset olivat seuraavanlaisia:

\section{Kun mummot omivat lapsen}

Onko muilla ollut ongelmia kun menee mummolaan niin lapsi viedään sylistä ja se vaipotellaan ja syötetään ja ei mitään asiaa koskea omaan lapseen niin kauan kuin on mummolassa. Jos vauva itkee niin ottaa mummot nokkiin jos yrittää edes itse ottaa lapsen syliin. Viimeksi vaipan vaihdossa mummo sanoi että menkää te siitä vahtimasta kyllä hän osaa. (pissi valui ohi vaippojen sen jälkeen, oli liian löysällä vaippa). Kuinka sanoa asiasta nätisti että lapsi tarvitsee vanhempiaan ja ei saa työntää äitiä ja isiä pois lapsen luota, ikääkin vain 2 kuukautta. Onko muilla kokemuksia yli innokkaista mummoista jotka elää omaa vanhemmuuttaan uuden lapsen kautta? (A1)

\section{En saa olla yhteydessä lapsenlapsiini}

Olen suruissani. Minulla on ikävä lapsenlapsiani, jotka asuvat toisella paikkakunnalla. Haluaisin joskus heitä kylään tai käydä katsomassa. En ole varma onko lapset huostaan otettu. On noin puoli vuotta kun näin lapset viimeksi - silloinkin sain hoitaa heitä vain hetken. Vanhemmat ovat suuttuneet minulle kun en pystynyt auttamaan heitä 
heidän kotinsa kotitöissä - kun olen itsekin työssä ja etäisyyttä heidän paikkakunnalleen on melkein sata kilometriä - enkä omista ajokorttia. Facebookissa sain jonkin aikaa pitää yhteyttä vanhimpaan lapsenlapseeni, mutta nyt sekin on kielletty, samoin puhelinsoitot. Miniäni sanoi, että tälle lapsenlapselle, joka on vähän vanhempi, on kerrottu että kaikki vaikeudet kuten mm. kunnan lasten huostaanottoaikomukset ovat minun syytäni. En saa edes soittaa lapsenlapsilleni - en pitää mitään yhteyttä. Hoidin näitä lapsenlapsia, näiden ollessa pieniä aika paljon myös silloin kun vanhemmat tekivät joitakin lomamatkoja - pitempiäkin aikoja. Lasten vanhempien elämä on mennyt raiteiltaan ja molemmilla on nykyään rikostaustaa. Olen työssäkäyvä tavallinen mummeli, joka vietän ihan tavallista elämää - en tiedä, miten jaksan elää tämän asian kanssa. Minun on niin ikävä. (A2)

\section{Lastenlasten eriarvoisuus}

Mikä neuvoksi, vai onko enää mitään tehtävää... Isovanhemmat paapovat toisen lapsen jälkeläisiä niin, ettei omillamme ole enää sijaa eikä mitään osaa eikä arpaa heidän elämässään. Toisen lapsen lapsia pidetään yökylässä joka viikonloppu, vaikka he ovat hoidossa viikolla päiväkodissa. Itse hoidan lapset kotonani (teen silti töitä kotona), mutta haluaisin joskus edes saada vapaa-aikaa mieheni kanssa, jolloin voisimme käydä ulkona vaikka syömässä, mutta tämän toisen perheen molemmat vanhemmat käyvät työssä kodin ulkopuolella ja pitävät lapsiaan jatkuvasti hoidossa isovanhemmilla. Olen koittanut vihjailla asiasta, mutta aina tulee vastaus "kyllä ne kaikki tänne sopii". Omaa poikaani on isoäidin toimesta haukuttu lellityksi, kun hänellä oli kahden vuoden uhma... siksi en halua viedä lapsiani samaan aikaan hoitoon niiden "kilttien" lasten kanssa. Tämän toisen perheen 10 v. riehui siellä, ja häntä piti "ymmärtää". (A3)

\section{Isoäiti ei auta..}

Minulla on tämmöinen tilanne elämässä, että olen yh-äiti jonka lapsen isä lähti heti kuultuaan raskaudesta. Ja minun äitini ei ollut aluksi niin iloinen tilanteesta mutta oppi sitten iloitsemaan tulevasta lapsen lapsesta. Mutta hän ei auta minua lapsen kanssa. Lapseni on noin 5-vuotias. Hän sanoo että ei ole hänen hommansa hoitaa tai kasvattaa lastani. Ja olen sanonut että hänen ei tarvitse, kunhan joskus olisi hänen kanssaan. Lapseni on ollut mummulassa yötä n. 4 kertaa koko ikänsä aikana ja hyvin vähän äitini ottaa häntä hoitoon muutenkaan. Hän vetoaa siihen usein että ei hän saanut minunkaan kanssa apua niin miksi minua pitäisi auttaa... Tuntuu pahalta että hän purkaa oman "kaunansa" meihin... (A4)

Aloitukset virittävät keskustelemaan myös asioista, jotka vain väljästi, jos ollenkaan, liittyvät aloittajan kuvaamaan ongelmatilanteeseen. Puhutaan esimerkiksi monen keskustelijan voimin Ylen dokumentista. Vastaavasti, kun keskustelun aiheeksi on esitetty, että isoäiti ei auta, pohditaan sitä, miksi isän sukulaiset eivät tiedä lapsesta. Joku taas tarjoaa myönteistä toimintatapaa: "Olen tutustunut erääseen filosofiaan/ elämäntaitoon nimeltä Alkuajatus... " tai joku voi ruveta puhumaan astrologiasta. Keskustelupalstoilla puhutaan myös siitä, että lapsia pidetään päiväkodissa vuodet läpeensä, tai voidaan ryhtyä keskustelemaan neuvolan hoito-ohjeista. Rajaan aineistosta analyysin ulkopuolelle sellaiset kommentit, jotka eivät keskustele aloittajan esille tuomasta ongelmasta.

\section{AINEISTON ANALYYSI}

Aloitin analyysin lukemalla palstojen kommentit moneen kertaan. Tämän jälkeen määritin luokitteluyksiköksi kommentin eli erillisen vastauksen aloitukseen (ks. Graneheim \& Lundman 2004,106). Tarkastelin kutakin kommenttia siitä näkökulmasta, miten se reagoi aloitukseen. Myönteiseksi luokittelin kommentin, jos siinä osoitettiin myötämielisyyttä aloitukseen. Myös neutraalit neuvot luokitin myönteisiksi kommenteiksi. Näin ollen myönteisellä verkkovuorovaikutuksella tarkoitan kommentteja, jotka viestivät samanmielisyyttä tai neutraalia suhdetta aloitukseen tai aloittajaan. Mikäli taas aloitukseen suhtauduttiin kielteisesti, luokitin kommentin kokonaisuudessaan kielteiseksi. Kielteinen verkkovuorovaikutus tarkoittaa artikke- 
lissani kommentteja, jotka osoittavat erimielisyyttä aloitukseen tai aloittajaan.

Perustelen määrittelyäni myönteiseksi ja kielteiseksi vuorovaikutukseksi saman-/erimielisyyden näkökulmista sen mukaan, saisiko kommentti aloittajan tuntemaan olonsa paremmaksi (= myönteinen) vai huonommaksi (= kielteinen) (ks. Colineau \& Paris 2010, 143). Olen valinnut kommentista virkkeen, joka mielestäni kuvaa kommentin suhdetta aloitukseen. Tiivistin siis myönteisiä sekä kielteisiä lausumia kuvaavat vastauskokonaisuudet. Aineistolähtöisen luokituksen jälkeen käsitteellistin myönteiset lausumat Bradyn \& Guerinin (2010) luokittelua soveltaen emotionaaliseksi tueksi, välineelliseksi tueksi ja $y$ ksilön suojeluksi. Esimerkiksi tiivistys "oletko ottanut selvää" muodosti osan alakategoriasta neuvojen antaminen. Tilanteen tai toiminnan myötäily, ymmärrys oman kokemuksen kautta sekä myötätunnon ilmaisu muodostivat yläkategorian nimeltään emotionaalinen tuki. Tulkitsin alakategorioiden ilmentävän tukea aloittajalle tai saavan aloittajan tuntemaan olonsa paremmaksi (ks. Brady \& Guerin 2010; Colineu \& Paris 2010). Kielteiset kommentit käsitteellistin avoimeksi ilkeilyksi ja piilo-ilkeilyksi Muikku-Wernerin (2004) mukaisesti. Esitän tuloksia ja tekemiäni päättelyketjuja taulukoissa $\mathbf{1}$ ja $\mathbf{2}$ (ks. Elo \& Kyngäs 2008, 112).

\section{TULOKSET}

\section{Tukea verkkokeskustelupalstalla}

Aloituksen näkökulmasta myönteinen verkkovuorovaikutus apua ja tukea pyytäville keskustelun aloittajille isovanhempiin liittyvillä palstoilla

Tarkastelen myönteistä verkkovuorovaikutusta keskustelupalstoilla taulukon 1 mukaisesti siten, että tarkastelen ensin keskustelussa annettua välineellistä tukea. Välineellisen tuen jaan (1) neuvojen antamiseen, (2) neutraaleihin toteamuksiin sekä (3) konfliktoitumiseen yllyttämiseen Fukkinkin (2011) sekä Brady \& Guerin (2010) mukaisesti. Välineellinen tuki liittyy erilaisten ratkaisujen, informaation ja neuvojen antamiseen ongelman ratkaisemiseksi. Erilaisten neuvojen laatua tulisi kuitenkin tarkastella kriittisesti, kuten esimerkiksi konfliktoitumiseen yllyttäminen osoittaa.

\section{Välineellinen tuki}

Neuvojen antaminen osana välineellistä tukea määrittyi erilaiseksi aloituksesta riippuen. Aloitukseen, joka käsitteli sitä, että isovanhempi ei saanut olla yhteydessä lapsenlapsiin (A2) annettiin seuraavankaltaisia neuvoja:

"Oletko ottanut selvää näistä kiemuroista?" "Otappas vaan yhteyttä sinne sossulaan; etkö voisi olla yhteydessä heidän lastensuojeluun."

Ehdotetaan siis asiantuntijaorganisaation puoleen kääntymistä. Näillä neuvoilla aloittajaa rohkaistaan toimimaan yhdessä asiantuntijan kanssa, jotta hänen kipeästi kokemansa tilanne, jossa hän ei saa olla yhteydessä lapsenlapsiin, ratkeaisi. Lastenlasten eriarvoisuus (A3) virittää monia neuvoja:

".järjestäisin lapselleni hoitopaikan." "Ottaa varmasti asia puheeksi, kuten sinunkin?" "Älä takerru ja jää murehtimaan yhtä asiaa johon et voi vaikuttaa."

Neuvot ovat siis varsin konkreettisia toimintaohjeita esimerkiksi hoitopaikan hakemiseen tai isoäidin kanssa keskustelemiseen. Näiden neuvojen tavoitteeksi voi tulkita aloittajan tilanteen parantamisen. Toisaalta neuvot voivat pyrkiä ohjaamaan aloittajaa ajattelutavan muuttamiseen (älä takerru) ja olemassa olevan tilanteen hyväksymiseen.

Välineellisen tuen alakategoriaksi olen tulkinnut erilaiset neutraalit toteamukset. Näissä sitaateissa ei otettu erityisemmin kantaa esitettyyn aloitukseen, vaan kuvataan olemassa oleva tilanne:

"Isovanhemmilla ei ole lapsenlapsiin minkäänlaista laillista oikeutta L" (A2) "Kyllähän se kuulostaa siltä, että isovanhemmat eivät toimi viisaasti ja tasapuolisesti, mutta sellaistahan elämä vaan on." (A3)

Muussa tekstin osassa voidaan sitten tarkastella aloittajan tilannetta, mutta keskeistä tässä on pyrkimys neutraaliuteen. Neutraaliuden ja kantaaottamattomuuden tulkitsen jonkinlaiseksi oikeudenmukaisuuteen pyrkimiseksi: halutaan olla ottamatta kantaa puolesta tai vastaan. Hymiöllä voidaan kuitenkin viestiä, että vaikka laillista oikeutta ei ole, tämä ei ole mukava asia. 
Taulukko 1. Aloituksen näkökulmasta myönteisen verkkovuorovaikutuksen luokitus välineelliseen ja emotionaaliseen tukeen sekä yksilön suojeluun.

Välineellisen tuen kiistanalainen alakategoria on konfliktoitumiseen yllyttäminen. Tässä lähtökohtana on myönteinen suhde aloitukseen, mutta tuki saa sellaisen muodon, että se suosii välien rikkoutumista. Annetaan siis toimintaohjeita ja neuvoja, joiden laatu on kyseenalainen:

"ei tarvi sanoa nätisti... sillä sinun äitisikään ei käyttäydy nätisti. lapsesi on sinun joten silläkin uhalla, että välit katkeaa on tehtävä asia selväksi. Ja onko siellä mummolassa aivan pakko rampata..." (A1)

Äärimmillään ohjeeksi tarjotaan epäsuorasti isovanhemman hylkäämistä:

"minä olen hyljännyt tuollaisen isovanhemman jo aikoja sitten. ${ }^{* * * *}$ mikä *****." (A3)

Sitaatin tähdet lienevät kiroilemisen symboleja, jolloin kirosanoilla vahvennetaan ohjetta hylätä isovanhempi. Näin annetaan neuvoja ja toimintaohjeita, jotka perheen ihmissuhteiden näkökulmasta eivät ole rakentavia ja ihmissuhteita tukevia.

\section{Emotionaalinen tuki}

Emotionaalinen tuki muodostuu tilanteen tai toiminnan myötäilystä, ymmärryksestä oman kokemuksen kautta sekä myötätunnon ilmaisusta. Näillä emotionaalisen tukemisen muodoilla osoitetaan empatiaa aloittajalle.

Emotionaalisen tuen erääksi muodoksi tulkitsen siis aloittajan ratkaisun tai toiminnan myötäilyn. Annettu vas-

\begin{tabular}{|c|c|c|}
\hline Tiivistys & Alakategoria & Yläkategoria \\
\hline $\begin{array}{l}\text { Ei sinun tarvitse olla varpaillasi ja } \\
\text { totella mummoa. Sanot vain,... (A1) } \\
\text { Oletko ottanut selvää (A2) } \\
\text { Etkö voisi olla yhteydessä (A2) } \\
\text { Hae lapselle virikehoito-paikkaa (A4) }\end{array}$ & $\begin{array}{l}\text { Neuvojen } \\
\text { antaminen }\end{array}$ & \\
\hline $\begin{array}{l}\text { Isovanhemmilla ei laillista oikeutta } \\
\text { (A2) } \\
\text { Isovanhemmat eivät toimi } \\
\text { tasapuolisesti (A3) } \\
\text { Yksilökohtaista miten } \\
\text { isovanhempien seuraa tarjotaan (A3) }\end{array}$ & $\begin{array}{l}\text { Neutraali } \\
\text { toteamus }\end{array}$ & $\begin{array}{l}\text { Välineellinen } \\
\text { tuki }\end{array}$ \\
\hline $\begin{array}{l}\text { Suuttukoon mummu (A1) } \\
\text { Uhalla, että välit katkeavat (A1) } \\
\text { Vähentäkää mummolakäyntejä (A1) } \\
\text { Hylkää isovanhempi (A3) } \\
\text { Sosiopaatteihin ei auta muu, kuin } \\
\text { luoti (A3) }\end{array}$ & \begin{tabular}{c|} 
Konfliktoitumiseen \\
yllyttäminen
\end{tabular} & \\
\hline $\begin{array}{l}\text { Voi nätisti sanoa (A1) } \\
\text { Moni yh toivoisi joskus vapaata } \\
\text { lapsenhoidosta (A4) } \\
\text { Ei outoa toivoa apua (A4) }\end{array}$ & $\begin{array}{l}\text { Tilanteen tai } \\
\text { toiminnan } \\
\text { myötäilyä }\end{array}$ & \\
\hline $\begin{array}{l}\text { Olen myös yksi niistä (A2) } \\
\text { Meillä sama (A3) } \\
\text { Täällä toinen äippä (A3) } \\
\text { Minullakin on kaunoja (A4) }\end{array}$ & $\begin{array}{l}\text { Ymmärrys oman } \\
\text { kokemuksen } \\
\text { kautta }\end{array}$ & $\begin{array}{l}\text { Emotionaalinen } \\
\text { tuki }\end{array}$ \\
\hline $\begin{array}{l}\text { Olet ajatuksissani (A2) } \\
\text { Minusta todella ikävä (A3) } \\
\text { Olen pahoillani (A4) }\end{array}$ & $\begin{array}{l}\text { Myötätunnon } \\
\text { ilmaisu }\end{array}$ & \\
\hline Mikä oikeuttaa sinut ...(A4) & \begin{tabular}{|c|} 
Ristiriitojen \\
tarkoituk- \\
sellisen luomisen \\
oikeutuksen \\
kiistäminen \\
\end{tabular} & \\
\hline $\begin{array}{l}\text {... älä ainakaan välitä tuosta } \\
\text { viestistä... (A2) }\end{array}$ & $\begin{array}{l}\text { Moitteen } \\
\text { oikeutuksen } \\
\text { kiistäminen }\end{array}$ & Yksilön suojelu \\
\hline $\begin{array}{l}\text {...listan tekijää ainakin vaivaa } \\
\text { sairaalloinen ylemmyyskompleksi } \\
\text {... (A3) }\end{array}$ & $\begin{array}{l}\text { Ilkeilijän } \\
\text { luonnehdinta }\end{array}$ & \\
\hline $\begin{array}{l}\text {... joka ei millään tavalla liipaise } \\
\text { sinun tilannettasi (A3) }\end{array}$ & $\begin{array}{c}\text { Aihepiirin ohipuhu- } \\
\text { misesta } \\
\text { moittiminen }\end{array}$ & \\
\hline
\end{tabular}


taus seuraa aloittajan itse tarjoamaa vihjettä ja näin emotionaalisesti ilmaisee samanmielisyyttä aloittajan kanssa: Kuinka sanoa asiasta nätisti..(A1):

"...voisi tosin nätisti sanoa että meillä tehdään näin, ja odottaa mummon kunnioitusta..."

"Mielestäni jokainen äiti voi sen aivan hyvin sanoa, jos ei halua mummojen..."

Myös aloituspuheenvuoron esittäjän toivetta saatettiin myötäillä:

"Moni yh toivoisi joskus vapaata lapsenhoidosta. Ei siinä ole mitään outoa." (A4)

Tällaisten myötäilyjen tulkitsen osoittavan samanmielisyyttä ja tukevan aloittajan toivetta ja näin voivan saada viestinnän osapuolen tuntemaan olonsa paremmaksi (ks. Colineau \& Paris 2010).

Emotionaalista tukea osoitetaan myös oman kokemuksen tuoman ymmärryksen valossa.

"Olen myös yksi niistä mummeista, joka on saanut kokea lastensuojelun ennakkoluuloista suhtautumista isovanhempiin." (A 2)

Ymmärrys rakentuu aloituspuheenvuorossa esitetyn tilanteen lukemisesta omaan tilanteeseen soveltuvaksi:

"sama oli meilläkin. ei muistamista synttäreinä tai jouluna. Tyttäreni oli saman ikäinen kuin serkkunsa mummo puuhasi synttärikorttia tälle serkulle vaan ei meidän tytölle." (A3)

Tällaisissa tilanteissa päästään purkamaan myös omaa epäoikeudenmukaisuuden kokemusta samalla kun osoitetaan tukea aloituspuheenvuoron kirjoittajalle. Omaan kokemukseen vedoten ikään kuin vahvennetaan esitetyn ongelman oikeutusta.

Emotionaalisen tuen eräänä muotona ovat erilaiset myötätunnon ilmaisut.

"Minusta on todella ikävä AP:n kohdalla että heidän lapsiaan ei kohdella samanarvoisesti." (A3) "On kyllä erittäin surullista ja kummallista, että mummo ei koskaan halua auttaa yhtytärtään eikä hoivata lapsenlastaan." (A4) "Voimia sinulla [sic]! Olet ajatuksissani!" ( A2)
Osoittamalla myötätuntoa ja pukemalla se selkeiksi sanoiksi, voidaan aloittajan tunnetilaa tukea. Silloin annetaan ymmärtää, että aloittaja on kohdannut vääryyttä, josta verkkokeskustelija on samaa mieltä. Emotionaalinen tuki saa erilaisen muodon keskustelun aloituksesta riippuen. Samanarvoisen kohtelun puute, mummon haluttomuus auttaa sekä lapsenlapsesta eristäminen saavat aikaan myötätunnon ilmaisuja ja empatiaa.

\section{Yksilön suojelu}

Oman yläkategoriansa muodostivat erilaiset yksilön suojelun (vrt. Brady \& Guerin 2010, jotka puhuvat yhteisön suojelusta) ilmaukset. Näiden tulkitsin kuvaavan myönteistä suhtautumista aloittajan tilanteeseen puolustamalla aloittajan viestiä ja siihen kommentointia sopimattomilta viesteiltä. Yksilöä suojellaan kiistämällä keskustelijoiden oikeutta tarkoituksellisesti aiheuttaa ristiriitoja:

"Mikä oikeuttaa sinut nimittämään tuntematonta ihmistä lehmäksi. Ihan ystävällisestikin voit sanoa saman asian." (A4)

Tässä suojellaan aloittajaa avoimelta ilkeydeltä, kun kommentoidaan kommenttiviestin lähettäjää. Moite kohdistetaan sopimattomasti käyttäytyneelle ja aloittajaa suojellaan epäsuorasti.

Yksilöä suojellaan myös kun rohkaistaan aloittajaa olemaan huomioimatta kommenttia:

"Kuule, älä ainakaan välitä tuosta viestistä, jossa sinua moititaan lastesi kasvattamisesta!" (A2)

Yksilöä suojellaan kehottamalla olemaan välittämättä epäasiallisesta kommentista. Huutomerkillä vahvistetaan kehotusta. Huonoksi kasvattajaksi nimetyksi tuleminen on tilanne, jossa harva kasvattaja voi olla tuntematta pistoa sydämessään. Tällaisen moitteen ohittamisen voi nähdä aloittajan suojelemisena sekä epäsuorana moitteena epäasiallisesta keskustelusta.

Kun palstalla joku rupeaa nimittelemään, yksilöä voidaan suojella reagoimalla ilkeilijään luonnehtimalla hänen ominaisuuksiaan:

"Luulen, että listan tekijää ainakin vaivaa sairaalloinen ylemmyyskompleksi, kun pitää yrittää karsi- 
noida tuntemattomia ihmisiä muutaman rivin perusteella". (A3)

Tällöin annetaan niin sanotusti samalla mitalla kuin muistutuksena siitä, millaista on sopimaton keskustelu verkossa. Kommentoijan annetaan tuntea, miltä epäsopiva keskustelu tuntuu.

Lisäksi yksilön suojeluksi voi määrittää moittimisen ohipuhumisesta silloin, kun keskustelu menee aihepiirin ohi:

"Mikä ihmeen pakko sinun on tulla inttämään ja väittämään keskusteluosioon joka ei millään tavalla liipaise sinun tilannettasi läheltäkään?" (A3)

Keskustelun aloituksen katsotaan tässä tapauksessa muodostavan legitiimin puheenaiheen, jonka puitteissa keskustelun tulisi jatkua. Kommenttipuheenvuoron esittäjän näkökulmasta se edellyttäisi nimenomaan keskustelun aiheen, eli tässä tapauksessa lastenlasten eriarvoisen kohtelun, kommentointia.

\section{Ilkeilyä verkkokeskustelupalstalla}

Aloituksen näkökulmasta kielteinen verkkovuorovaikutus apua ja tukea pyytäville keskustelun aloittajille isovanhempiin liittyvillä palstoilla

Kielteistä verkkovuorovaikutusta jäsentävän taulukon 2 avulla tarkastelen tuloksia yksityiskohtaisesti. Lähtökohtana ovat kommentit, jotka suhtautuvat aloittajaan tai hänen viestiinsä kielteises-

ti. Tarkastelen keskustelussa esitettyjä puheenvuoroja piiloilkeilyn ja avoimen ilkeilyn näkökulmista (ks. Muikku-Werner 2004). Verkkokeskusteluissa haetaan yhteyttä toisiin keskustelijoihin sekä pyydetään suoranaisia neuvoja ja tukea ongelmatilanteisiin. Tällöin ilkeilyä voi pitää aloituksissa kuvattuihin ongelmatilanteisiin ja niiden pohjalta syntyneisiin odotuksiin nähden hyvin epätoivottavana reaktiona.
Taulukko 2. Kielteisen verkko-vuorovaikutuksen luokitus piilo-ilkeilyksi ja avoimeksi ilkeilyksi.

\begin{tabular}{|c|c|c|}
\hline Tiivistys & Alakategoria & Yläkategoria \\
\hline $\begin{array}{l}\text { Ei halua tiettyjä lastenlapsia kotiinsa } \\
\text { (A3) } \\
\text { Lapsi ei kunnon kansalainen (A2) } \\
\text { Lastensuojelu suojelee } \\
\text { isovanhemmilta (A2) } \\
\text { Läheinen suhde isovanhempaan ei } \\
\text { lapsen etu (A4) } \\
\text { Hoitoon kelpaamaton lapsi (A3) }\end{array}$ & $\begin{array}{l}\text { Kasvatus- } \\
\text { kyvyttömyys }\end{array}$ & \multirow{2}{*}{ Piiloilkeily } \\
\hline $\begin{array}{l}\text { Pullamössövanhempien } \\
\text { sairas mielikuvitus (A1) } \\
\text { Lapsipolven lapsen tekeminenkö } \\
\text { ihailtavaa (A4) } \\
\text { Nuoret tavoittelevat apua ja omaa } \\
\text { aikaa (A3) }\end{array}$ & Sukupolviristiriita & \\
\hline $\begin{array}{l}\text { Turhaa valittamista (A1) (A3) } \\
\text { Luulet vain syrjittävän (A3) } \\
\text { Huolehdittava itse lapsesta (A4) } \\
\text { Ei isoäidin velvollisuus auttaa (A4) } \\
\text { Huolet sullakin (A1) }\end{array}$ & $\begin{array}{l}\text { Ongelman } \\
\text { oikeutuksen } \\
\text { kiistäminen }\end{array}$ & \multirow[b]{2}{*}{ Avoin ilkeily } \\
\hline $\begin{array}{l}\text { Typerä teini (A4) } \\
\text { Kuulostat aivottomalta (A1) } \\
\text { Mielenterveys kyseenalaista (A1) } \\
\text { Tyly ihminen (A1) } \\
\text { Kateellinen marttyyri (A3) } \\
\text { Säälittävä, hävettävä (A4) } \\
\text { Lukuisia herjaavia nimittelyjä (A3) }\end{array}$ & $\begin{array}{c}\text { Henkilökohtaista } \\
\text { solvaamista }\end{array}$ & \\
\hline
\end{tabular}

\section{Piiloilkeily}

Kun tarkastellaan perheen ihmissuhteita ja annetaan vanhempien epäsuorasti ymmärtää, että he ovat huonoja kasvattajia, voi tätä mielestäni pitää osoituksena piiloilkeilystä.

"Emme todellakaan halua näitä toisen tyttäremme kolmea jälkeläistä kotiimme." (A3) "Juuri tuon kirjoittamasi viimeisen kappaleen vuoksi lastensuojelu katkaisee välit huostaan otettujen lasten isovanhempiin." (A2) 
Näille lausumille on ominaista, että ei puhuta suoraan aloittajasta (ks. Muikku-Werner 2004), vaan analogian avulla aloittaja tulee tulkituksi tyttären kaltaiseksi tai isovanhemmaksi, jolta lastensuojelu suojelee lastenlasta. Juuri epäsuoruus ilkeilyn esittämisessä on näissä kommenteissa olennaista.

"Eikö heillekään kelpaa sinun lapsesi hoitoon?" (A3).

Tässäkään lausumassa ei sanota aivan suoraan, vaan annetaan epäsuorasti ymmärtää aloittajan olevan huono kasvattaja, jolloin tämäkin on esimerkki piiloilkeilystä. Mainitut esimerkit luonnehtivat epäsuorasti kirjoittajaa kasvatuskyvyttömäksi.

Piiloilkeilynä näen myös sukupolvien välisen ristiriidan.

"En näe, ..., mitään sairasta mummien touhutessa pikkupilttien ympärillä, vaan näiden pullamössövanhempien sairaaloisessa mielikuvituksessa, että isovanhemmat yrittävät jollain tavalla kaapata heidän tuotoksiaan." (A1)

"Tuntuu että usein on kyse siitä, että lapsipolvi hakee kiitosta ja ylistystä/palvontaa siitä että TEKIVÄT lapsen." (A4)

"Jotenkin teidän nuorten pitää kyllä jatkuvasti apua saada ja omaa aikaa, kuulkaas nyt hoitakaa itse omat lapsenne ja sitten kun mummolaan voi mennä he kyllä pyytävä." (A3)

Piiloilkeilytulkinnan lähtökohtana on, että vastaukseen tuodaan sukupolvien välinen ristiriita yleiseksi selitysmalliksi. Tämä selitysmalli näyttää toimivan, olipa kyse lastenlasten erilaisesta kohtelusta tai siitä, että yksinhuoltajaäiti kaipaa isoäidiltä huolenpitoapua tai kun koetaan, että mummot omivat lapsen. Isoilla kirjaimilla huudetaan, että pelkkä lapsen tekeminen riittää. Tässäkin puhutaan aivan kuin yleisellä tasolla, eikä siis kohdisteta kommenttia suoraan aloittajaan. Tämän vuoksi tulkitsen sukupolvien väliseksi ristiriidaksi jäsentyvät kommentit piiloilkeilyksi.

Piiloilkeilylle on myös ominaista erilainen vähättely. Voidaan esimerkiksi kiistää aloittajan kuvaaman isovanhempien ja lastenlasten välisten ongelmien oikeutusta ja pitää niitä perusteettomina:

"Älä höyryy turhasta!" (A1)
"Pienet on sulla huolet. Auttaa ne vaan yrittäa." (A1) Voidaan myös vähätellä aloittajan tulkintaa tilanteesta:

"Saattaa olla että vain luulet lastasi syrjittävän isovanhempien toimesta." (A3)

Ongelman oikeutusta voidaan lisäksi kiistää perustelemalla, että isovanhempien velvollisuus ei ole hoitaa lastenlapsia:

"Nyt minun pitäisi ottaa kolmekymppisen tyttären touhuista vastuu. Olen hänet kouluttanut, nyt pitäisi vielä sairaana hoitaa lasta öisin. Ei taida nyt sopia minulle lainkaan." (A3)

Ongelmalliseksi koettua ongelmaan voidaan kiistää vähättelemällä koko tilannetta:

"Huolet sullakin? Mikä siinä niin kovin ärsyttää, jos mummut hyysää? löysällä vaipat? LOL!" (A1)

Viimeksi mainittu kommentti haastaa vähättelyn ohella nauramaan (LOL). Voi pohtia, onko tässä kyseessä Muikku-Wernerin (2005) ilkeilyn tulkintaa myötäilevä esimerkki niin sanotusta leikkisästä kiusoittelusta. Tämä on tulkintani mukaan kuitenkin esimerkki vähäisestä ilkeilystä. Se eroaa näkemykseni mukaan selvästi myönteisiin tavoitteisiin pyrkivästä hyväntahtoisesta kiusoittelusta.

\section{Avoin ilkeily}

Avointa ilkeyttä ilmenee palstoilla varsin monella tavalla. Nimetön palsta näyttää mahdollistavan henkilökohtaista solvaamista:

"pikkukko on typerä teini." (A1)

"Oletkohan terve? Onkohan sinulla kaikki muumit laaksossa?" (A1)

"Kasvaisit itsekin säälittävä horo lehmä! Olet häpeä!" (A4)

Huutomerkein ja kysymysmerkein vahvistetaan suoraa ilkeyttä. Äärimmillään avoin ilkeys saa sellaisen muodon, että asiaa ei edes kommentoida, vaan siirrytään suoraan pelkästään nimittelemään aloittajaa:

"Äippä vaan olet 1, Idiootti 2. Hölmö, ... 13. Joutava jne... Fyysisiä ominaisuuksia en voi listata mutta etköhän ole myös varsin ruma." (A3) 
Nimettömillä verkkosivustoilla voi siis purkaa omia aggressioitaan varsin estoitta. Pahimmillaan tällainen avoin ilkeily lähentelee kiusaamista, kun sama henkilö uudistaa useamman kerran omia herjaavia viestejä samalle kirjoittajalle (ks. Grigg 2010).

\section{POHDINTA}

Verkkokeskustelupalstat ovat eräs informaalisen oppimisen väylä, jossa voidaan antaa myönteisiä neuvoja ja toimintaohjeita sekä tukea emotionaalisesti vaikeaksi koetussa tilanteessa olevaa. Isovanhemmuuden teemoihin keskittyvät verkkokeskustelupalstat voivat tarjota sekä myönteisiä että kielteisiä informaalisen oppimisen kokemuksia vuorovaikutuksessa. Nämä vuorovaikutuskokemukset voivat joko tukea perheen ihmissuhteita tai toimia niitä vahingoittavina (esimerkiksi konfliktoitumiseen yllyttäminen), mikäli vastaavanlaisissa elämäntilanteissa olevat toimivat neuvojen ja palautteiden mukaisesti. Toista keskustelijaa voidaan myös tietoisesti pyrkiä vahingoittamaan kyseenalaistamalla hänen vanhemmuuttaan, herjaamalla häntä tai vähättelemällä koettua ongelmaa ja sen oikeutusta.

Aikuiskasvatuksellisesti verkkokeskusteluissa on kyse ennen kaikkea perhekasvatuksesta ja isovanhempien ja lastenlasten suhteista, joissa lasten vanhempien sukupolvi on merkittävässä roolissa. Ongelmalliset kasvatukselliset kysymykset liittyvät esimerkiksi tasapuoliseen suhtautumiseen lastenlapsiin, anopin ja miniän tai vävyn suhteiden kautta määrittyviin suhteisiin isovanhempiin ja heidän oikeuksiinsa olla mukana lastenlasten elämässä tai isovanhempien oikeuteen olla hoitamatta lastenlapsia niin halutessaan.

Verkon asiallisen käyttämisen korostaminen on myös aikuiskasvatuksellinen tehtävä. Tämän tutkimuksen luokitteluja voisi käyttää netti-etiketin opettamiseen. Luokitukset voisivat toimia keskustelun virittäjinä. Yhteiskunnallisesti voisi pohtia anonyymisyyttä ja sen oikeutusta. Anonyymisyys mahdollistaa erilaista vihapuhetta ja ilkeilyä verkossa hyvin eri tavoin kuin omalla nimellä kirjoitettaessa. Viimeaikainen vihapuhe ja uhkailu verkossa sekä tämän artikkelin avoin ja piiloilkeily asettavat mielestäni kyseenalaiseksi anonyymisyyden oikeutuksen.

Yhteiskunnallisesti on kyse siitä, miten hyväksyttävää ilkeily on - olipa sitten kyseessä verkko, televi- sio, lehdistö tai kasvokkainen vuorovaikutus ihmisten välillä (vrt. Muikku-Werner 2004, 2005). Mitä yleisempää ilkeily on, sitä helpommin voi ajatella sen leviävän yhteiskunnassa eri elämänalueille. Siksi on mielestäni tärkeää erotella käsitteellisesti toisistaan ilkeily leikkisästä kiusoittelusta, joka on tavoitteellisesti hyväntahtoista ja toista ihmistä rakentavaa, ja pahantahtoinen ilkeily. Pahantahtoinen suhtautuminen toisiin ihmisiin ei liene aikuiskasvatuksen tavoitteiden mukaista, liitetään sitten ilkeilyyn naurua tai ei. Ilkeilyn vastainen toiminta on mielestäni tärkeä yhteiskunnallinen aikuiskasvatuksellinen tehtävä.

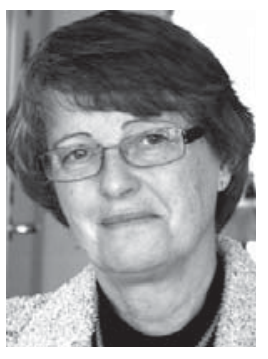

Ilse Eriksson

Dosentti, yliopistonlehtori Käyttäytymistieteiden laitos Helsingin yliopisto

\section{LÄHTEET}

Ahti, J.( 2011). Konfliktit verkkokeskustelussa uhkaava toinen vuoro ja affektiivisuus. Teoksessa Lehtinen, E., Aaltonen, S., Koskela, M., Nevansaari, E. \& Skog-Södersved, M. (toim.) 2011. Kielenkäyttö verkossa ja verkostoissa. AFinLAn vuosikirja 2011. Suomen soveltavan kielitieteen yhdistyksen julkaisuja n:0 69. Jyväskylä, 11-22.

Barth, J.C. (2004). Grandparents dealing with the divorce of their child: tips for grandparents and therapists. Contemporary Family Therapy 26(1), 41-44.

Brady, E. \& Guerin, S. (2010). "Not the romantic, all happy, coochy coo experience": A qualitative analysis of interactions on an Irish parenting web site. Family Relations 59(1), 14-27.

Connolly, M., Ward, T. (2008). Navigating human rights across the life course. Child and Family Social Work 13(3), 348-356.

Drentea, P. \&Moren-Cross, J.L. (2005). Social capital and social support on the web: the case of an internet mother site. Sociology of Health \& Illness 27(7), 920-943.

Doyle, M., O’Dywer, C. \& Timonen, V. (2010). "How can you just cut off a whole side of the family and say move on?" The reshaping of paternal grandparentgrandchild relationships following divorce or 
separation in the middle generation. Family Relations 59(5), 587-598.

Eibach, R.P. \& Mock, S. E. (2011). Idealizing parenthood to rationalize investments. Psychological Science 22(2), 203-208.

Elo, S. \& Kyngäs, H. (2008). The qualitative content analysis process. JAN Research Methodology 62(1), 107-115.

Fukkink, R.( 2011). Peer counselling in an online chat service: A content analysis of social support. Cyberpsychology, Behavior and Social networking, 14(4), 247-251.

Graneheim, U.H. \& Lundman, B. (2004). Qualitative content analysis in nursing research: concepts, procedures and measures to achieve thrustworthiness. Nurse Education Today 24. 105-112.

Grigg, D.W. (2012). Cyber-aggression: Definition and concept of cyberbullying. Australian Journal of Guidance \& Counseling, 20(2), 143-156.

Matikainen, J. (2000). Tietoverkkojen käytön sosiaalipsykologiaa. Mitä tietoverkkojen sosiaalipsykologia on? Teoksessa Matikainen, J. \& Manninen, J. Aikuiskoulutus verkossa. Verkkopohjaisten oppimisympäristöjen teoriaa ja käytäntöä. Helsingin yliopiston Lahden tutkimus- ja koulutuskeskus. Tampere, 43-59.

Matikainen, J. (2006). Vuorovaikutus ja sosiaalisuus verkossa. Teoksessa Aula, P., Matikainen, J. \& Villi, M. (toim.) Verkkoviestintäkirja: Helsinki: Yliopistopaino, 177-195.

Matikainen, J. (2011). Verkkokeskustelua homo-illasta - osallistumisen kulttuuria. Teoksessa Kivimäki, S. (toim.) Journalismikritiikin vuosikirja 2011. Tampere: Journalismikritiikin tutkimusyksikkö, 92-96.

McCormack, A. \& Coulson, N. (2009). Individuals with eating disorders and the use of online support groups as a form of social support. Cyberpsychology 3(2), 1-11.

Mo, P.K.H. \& Coulson, N.S. (2008). Rapid Communication. Exploring the communication of social support within virtual communities: A content analysis of messages posted to an online HIV/AIDS support group. Cyber Psychology \& Behavior 11(3), 371-374.

Muikku-Werner, P. (2004). Piruilun paluu piilopiikittelystä julkijulmuuteen. Teoksessa Muikku-Werner, P. \& Stotesbury, H. (toim.) Minä ja kielitiede - soveltajan arki. AFinLAn vuosikirja 2004. Suomen soveltavan kielitieteen yhdistyksen julkaisuja no. 62. Jyväskylä, 157-178.

Muikku-Werner, P. (2005). Ilkeilyn aiheet - saako kaikesta sanoa? Teoksessa Kuure, L., Kärkkäinen, E. \& Saarenkunnas, M. (toim.). Kieli ja sosiaalinen toiminta - Language and Social Action. AFinLA yearbook. Publications de l'association finlandaise de linguisique appliquée 63, 273-287.

O'Connor, H. \& Madge, C.(2004). 'My mum's thirty years out of date'. The role of the Internet in the transition to motherhood. Community, Work \& Family 7(3), 351-369.

O'Sullivan, P.B. \& Flanagin, A.J. (2003). Reconceptualizing 'flaming' and other problematic messages. New media \& Society, 2003, 5(1), 69-94.

Plantin, L. \& Daneback, K. (2009). Parenthood, information and support on the internet. A literature review of research on parents and professionals online. BMC Family Practice 10(34), 1-12.

Ristolainen, H., Hankonen, N. \& Lehtinen, V.l 2007). Sosiaalipsykologisia lähestymistapoja verkkovuorovaikutukseen. Psykologia 4, 276-288.

Turner, M.J., Young, C.R. \& Black, K.I. (2006). Daughters-in-law and mothers-in-law seeking their place within the family: a qualitative study of differing viewpoints. Family Relations 55(5), 588-600.

Turtiainen, R. \& Östman, S.(2013) Verkkotutkimuksen eettiset haasteet: Armi ja anoreksia. Teoksessa Laaksonen, S.-M., Matikainen, J., Tikka, M. (toim.) Otteita verkosta. Verkon ja sosiaalisen median tutkimusmenetelmät. Tampere: Vastapaino, 49-67.

Vanhanen, E. (2011). Vertaistuki verkkokeskustelussa - neuvottelevaa tukea ja autoritääristä auttamista. Janus 2011, 19(1), 36-51.

Walthers, J.B. \& Parks, M.R. (2002). Cues filtered out, cues filtered in. Computer-mediated communication and relationships. Teoksessa M. L. Knapp \& J.A. Daly.(Toim.) Handbook of interpersonal communication, 3rd edition. Thousand Oaks: Sage Publications. S. 529-563.

Yliopisto-lehti (2012). Suuttumus vie mennessään. Tähtivieras. Yliopisto. Helsingin yliopiston tiedelehti, 9,8 .

\section{VIITTEET}

1 Kiusoittelu määritellään (Muikku-Werner 2005. 274) aidoksi positiivisuudeksi, jonka tavoitteena on lisätä yhteenkuuluvuutta, vaikka se naamioidaan loukkaavaksi. Ongelmallista tällaisessa käsitemäärittelyssä on, että viestin vastaanottajaa tällainen voi loukata.

2 Näen hyväntahoisen kiusoittelun jatkumona, jonka toisessa päässä on erittäin vähäinen määrä kiusoittelua ja toisessa päässä erittäin suuri määrä kiusoittelua. En näe "valeilkeyttä" ilkeilyn alalajina, koska sen tavoitteena on antaa myönteistä palautetta (ks. Muikku-Werner 2004,158). 